\title{
Ammonia emissions from soil under sheep grazing in Inner Mongolian grasslands of China
}

\author{
YunHai ZHANG ${ }^{1,2}$, NianPeng $\mathrm{HE}^{3}$, GuangMing ZHANG ${ }^{1}$, JianHui HUANG ${ }^{1}$, QiBing WANG ${ }^{1}$, QingMin \\ PAN $^{1}$, XingGuo HAN ${ }^{1,4 *}$ \\ ${ }^{1}$ State Key Laboratory of Vegetation and Environmental Change, Institute of Botany, Chinese Academy of Sciences, Beijing 100093, \\ China; \\ ${ }^{2}$ University of Chinese Academy of Sciences, Beijing 100049, China; \\ ${ }^{3}$ Synthesis Research Center of Chinese Ecosystem Research Network, Institute of Geographical Sciences and Natural Resources \\ Research, Chinese Academy of Sciences, Beijing 100101, China; \\ ${ }^{4}$ State Key Laboratory of Forest and Soil Ecology, Institute of Applied Ecology, Chinese Academy of Sciences, Shenyang 110016, \\ China
}

\begin{abstract}
Ammonia $\left(\mathrm{NH}_{3}\right)$ emission and redeposition play a major role in terrestrial nitrogen $(\mathrm{N})$ cycles and can also cause environmental problems, such as changes in biodiversity, soil acidity, and eutrophication. Previous field grazing experiments showed inconsistent (positive, neutral, and negative) $\mathrm{NH}_{3}$ volatilization from soils in response to varying grazing intensities. However, it remains unclear whether, or to what extent, $\mathrm{NH}_{3}$ emissions from soil are affected by increasing grazing intensities in Inner Mongolian grasslands. Using a 5-year grazing experiment, we investigated the relationship between $\mathrm{NH}_{3}$ volatilization from soil and grazing pressure $(0.0,3.0,6.0$, and 9.0 sheep $/ \mathrm{hm}^{2}$ ) from June to September of 2009 and 2010 via the vented-chamber method. The results show that soil $\mathrm{NH}_{3}$ volatilization was not significantly different at different grazing intensities in 2009, although it was higher at the highest stocking rate during 2010. There was no significant linear relationship between soil $\mathrm{NH}_{3}$ volatilization rates and soil $\mathrm{NH}_{4}{ }^{+}-\mathrm{N}$, but soil $\mathrm{NH}_{3}$ volatilization rates were significantly related to soil water content and air temperature. Grazing intensities had no significant influence on soil $\mathrm{NH}_{3}$ volatilization. Soil $\mathrm{NH}_{3}$ emissions from June to September (grazing period), averaged over all grazing intensities, were $9.6 \pm 0.2$ and $19.0 \pm 0.2 \mathrm{~kg} \mathrm{~N} / \mathrm{hm}^{2}$ in 2009 and 2010, respectively. Moreover, linear equations describing monthly air temperature and precipitation showed a good fit to changes in soil $\mathrm{NH}_{3}$ emissions $(r=0.506, P=0.014)$. Overall, grazing intensities had less influence than that of climatic factors on soil $\mathrm{NH}_{3}$ emissions. Our findings provide new insights into the effects of grazing on $\mathrm{NH}_{3}$ volatilization from soil in Inner Mongolian grasslands, and have important implications for understanding $\mathrm{N}$ cycles in grassland ecosystems and for estimating soil $\mathrm{NH}_{3}$ emissions on a regional scale.
\end{abstract}

Keywords: $\mathrm{NH}_{3}$; $\mathrm{N}$ emission; grazing intensity; stocking rate; nitrogen cycle; Inner Mongolia

Citation: YunHai ZHANG, NianPeng HE, GuangMing ZHANG, JianHui HUANG, QiBing WANG, QingMin PAN, XingGuo HAN. 2013. Ammonia emissions from soil under sheep grazing in Inner Mongolian grasslands of China. Journal of Arid Land, 5(2): 155-165.

Ammonia $\left(\mathrm{NH}_{3}\right)$, the third most abundant gaseous nitrogen $(\mathrm{N})$ compound, plays an important role in terrestrial ecosystem $\mathrm{N}$ cycles, and affects the structure and function of terrestrial ecosystems (Asman et al., 1998; Myles, 2009). Atmospheric $\mathrm{NH}_{3}$ and its ionic form, ammonium $\left(\mathrm{NH}_{4}{ }^{+}\right)$, may influence the global climate by altering the transmission of atmospheric and terrestrial radiation (Xiao et al., 2012). In most cases, a large part of the emitted $\mathrm{NH}_{3}$ is quickly removed from the atmosphere through precipitation and dry deposition close to the source (Asman et al., 1998; Walker et al., 2004; Renner and Wolke, 2010). $\mathrm{NH}_{3}$ redeposited from the atmosphere may disrupt the $\mathrm{N}$ balance of natural ecosystems (Stevens and Tilman,

\footnotetext{
*Corresponding author: XingGuo HAN (E-mail: xghan@ibcas.ac.cn) Received 2012-09-26; revised 2012-11-27; accepted 2012-12-19

(C) Xinjiang Institute of Ecology and Geography, Chinese Academy of Sciences, Science Press and Springer-Verlag Berlin Heidelberg 2013
} 
2010; Sheppard et al., 2011). For example, increased $\mathrm{NH}_{4}{ }^{+}$input can lead to changes in soil nutrient availability, soil acidity, and plant species composition in grassland ecosystems adjacent to highly industrialized areas or livestock feedlots (Smart et al., 2011).

Grazing is the main land-use type of grasslands worldwide (He et al., 2012). Herbivore feeding and $\mathrm{NH}_{3}$ volatilization are two important pathways of $\mathrm{N}$ loss in grassland ecosystems. It is estimated that global annual $\mathrm{NH}_{3}$ emissions from grasslands and dry areas are within the range $0-10 \mathrm{~kg} \mathrm{~N} / \mathrm{hm}^{2}$ (Schlesinger and Hartley, 1992), and that annual $\mathrm{NH}_{3}$ emissions from undisturbed terrestrial soils are $4 \times 10^{9}-28 \times 10^{9} \mathrm{~kg}$ $\mathrm{N}$ (Bowden, 1986). Therefore, quantifying $\mathrm{N}$ loss from soil, especially by $\mathrm{NH}_{3}$ volatilization, is critical to understanding grassland $\mathrm{N}$ cycles (Bolan et al., 2004; Frank et al., 2004). It might be expected that $\mathrm{NH}_{3}$ emissions from soil would increase with increasing grazing intensity; however, the relationship between grazing intensities and $\mathrm{NH}_{3}$ emissions from soil is inconsistent: positive (Bowden, 1986; Frank and Zhang, 1997), neutral (Xu et al., 2010), and negative relationships (Ruess and McNaughton, 1988) have been reported, and a few studies have been conducted in both undisturbed and grazed grasslands (Denmead et al., 1974; Webb and Misselbrook, 2004). Clarisse et al. (2009) reported global atmospheric $\mathrm{NH}_{3}$ concentrations using infrared satellite observations. However, the overall $\mathrm{NH}_{3}$ emission rates from soils remain inadequately studied, particularly in the remote areas of developing countries. The Eurasian steppe is the world's largest terrestrial biome with alkaline soils. The effects of grazing intensity on soil $\mathrm{NH}_{3}$ emissions have significant implications for regional and global grassland $\mathrm{NH}_{3}$ budgets (Battye et al., 2003). Grazing intensities have increased sharply since 1980 (Feng and Zhao, 2011), with rapidly increasing human food demand in the region (Jiang et al., 2011). Increasing sheep stocking rate would increase the amounts of feces and urine excreted. Many researchers have reported greater $\mathrm{NH}_{3}$ emissions when the amount of feces increased (Hutchings et al., 1996; Bolan et al., 2004). However, there has been less focus on $\mathrm{NH}_{3}$ emissions from soils than on community-level effects in response to changes in grazing pressure. To date, no soil $\mathrm{NH}_{3}$ emissions data are available for this region.
Therefore, information from field grazing experiments is urgently required in order to explore the effects of increasing grazing intensities on soil $\mathrm{NH}_{3}$ emissions.

Based on a 5 -year grazing experiment (grazing intensities: $0.0,3.0,6.0$, and 9.0 sheep $/ \mathrm{hm}^{2}$, respectively) in Inner Mongolian grasslands (Schönbach et al., 2009), we investigated the relationship between soil $\mathrm{NH}_{3}$ emissions and grazing intensity. The main objectives of the study are to address the following three questions: 1) Do $\mathrm{NH}_{3}$ emissions from soil increase with increasing grazing intensities in Inner Mongolian grasslands? 2) What are the main factors controlling soil $\mathrm{NH}_{3}$ emissions in grazing grasslands? 3) What are their underlying mechanisms?

\section{Materials and methods}

\subsection{Study area}

The study area is located in the Xilin River Basin in Inner Mongolia autonomous region, China, and is representative of the Eurasian semi-arid steppe (Chen, 1988). The area is managed by the Inner Mongolia Grassland Ecosystem Research Station $\left(43^{\circ} 38^{\prime} \mathrm{N}\right.$, $116^{\circ} 42^{\prime} \mathrm{E}$ ) of Chinese Academy of Sciences. The annual mean temperature for $1981-2010$ was $0.4^{\circ} \mathrm{C}$, with the monthly mean temperature being $-21.4^{\circ} \mathrm{C}$ in January and $19.0^{\circ} \mathrm{C}$ in July, respectively. Annual precipitation was $355.0 \mathrm{~mm}$, with about $70 \%$ occurring from June to September. The temperature and precipitation during the grazing periods in 2009 and 2010 are shown in Fig. 1. The soils were classified as Calcic chernozems (Wang and Cai, 1988), with a $\mathrm{pH}$ value of 7.6 (soil:water=1:2.5). The study area was previously used as high-density free-grazing livestock site (Wang and Baoyin, 2005).

\subsection{Experimental design}

The grazing experiment was started in 2005, and experimental treatments were previously described in detail by Schönbach et al. (2009). The grazing experiment was operated by the Inner Mongolia Grassland Ecosystem Research Station within a multi-disciplinary international cooperation project (MAGIM, Matter fluxes in grasslands of Inner Mongolia as influenced by stocking rate). In brief, the grazing experiment used two management systems-traditional versus mixed (grazing and 

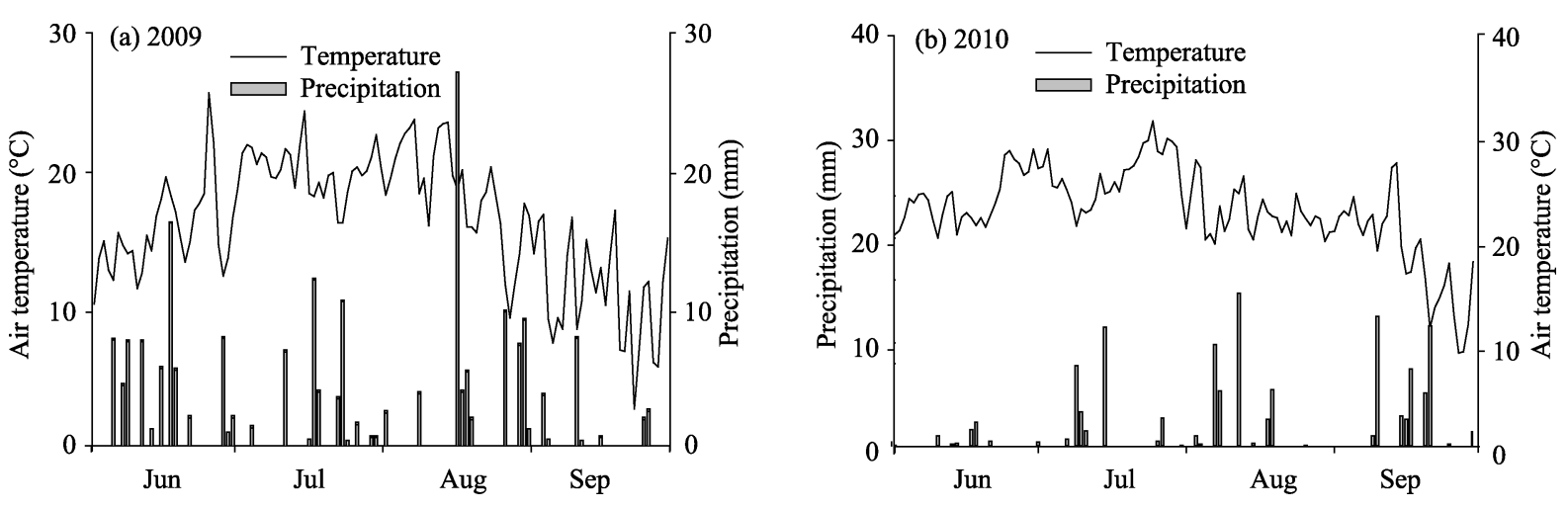

Fig. 1 Daily air temperature and precipitation during the sampling periods in 2009 (a) and 2010 (b)

hay-making alternated annually), and seven levels of grazing intensity (Grazing intensitiy $(\mathrm{GI})=0.0,1.5,3.0$, 4.5, 6.0, 7.5, and $9.0 \mathrm{sheep} / \mathrm{hm}^{2}$ ). Two-year-old female sheep were chosen for the grazing experiment. Each experimental treatment covered an area of $2 \mathrm{hm}^{2}$, and each plot was fenced separately against sheep migration at the beginning of the experiment. Grazing was continuous from June to September in each grazing area, which coincided with the vegetation growth period in the region (Schönbach et al., 2009). We selected four levels of grazing intensity (i.e., 0.0, 3.0, 6.0, and 9.0 sheep $/ \mathrm{hm}^{2}$ ) to investigate soil $\mathrm{NH}_{3}$ volatilization in the traditional system, representing a gradient of grazing intensities from June to September. Soil $\mathrm{NH}_{3}$ emissions in other months were not measured, because of the low temperature in the study area.

\subsection{Sampling and analysis}

We established 6 sampling subplots $(5 \mathrm{~m} \times 5 \mathrm{~m})$ along a diagonal line in each selected treatment site. All sub-plots were located more than $15 \mathrm{~m}$ from the boundary fence in order to avoid edge effects. We randomly set one polyvinyl chloride core (PVC, 152 $\mathrm{mm}$ in diameter and $150 \mathrm{~mm}$ in height) in each subplot; the core was inserted into the ground to a depth of $5 \mathrm{~cm}$. Soil $\mathrm{NH}_{3}$ emissions were directly measured by the vented-chamber method, which was modified from Wang et al. (2004). Our laboratory experiments showed that this method had a recovery rate of $>87 \%$ for soil $\mathrm{NH}_{3}$ volatilization. Moreover, some studies also reported that this method could reliably estimate $\mathrm{NH}_{3}$ emissions from soils. For example, Wang et al. (2004) reported that the recovery rate of emitted $\mathrm{NH}_{3}$ was very high $(99 \%)$ by treating low concentrations of $\mathrm{NH}_{4} \mathrm{Cl}$ with $\mathrm{NaOH}$. Sponges $(16 \mathrm{~cm}$ in diameter and 2 $\mathrm{cm}$ in thickness) were cut from larger pieces (Yellow-Flower brand, Xilinhot Sponge Corporation, Xilinhot, China). Each sponge was soaked with $10 \mathrm{ml}$ of trapping solution, which comprised a mixture of concentrated $\mathrm{H}_{3} \mathrm{PO}_{4}(50 \mathrm{ml})$, glycerol $(40 \mathrm{ml})$, and deionized water $(910 \mathrm{ml})$ (Wang et al., 2004; Liu et al., 2007a). A sponge soaked with the trapping solution was first inserted into the PVC core (4 cm in depth) in order to trap volatilized $\mathrm{NH}_{3}$ from soil $(24 \mathrm{~h}$, from 09:00 to 09:00 the next day); then, another (above) sponge was inserted into the PVC core to ensure that only the $\mathrm{NH}_{3}$ volatilized from soil was captured by the first (below) sponge that was to be used for $\mathrm{NH}_{4}{ }^{+} \mathrm{N}$ extraction. The two pieces of sponge were approximately $2 \mathrm{~cm}$ apart.

At each sampling event, granular sheep feces and aboveground plants in the PVC cores were removed $24 \mathrm{~h}$ before sampling, and the feces were returned to the core after samples were taken. We removed the plants and sheep feces because we only wanted to estimate the $\mathrm{NH}_{3}$ emissions from the soil (Wang et al., 2004; Liu et al., 2007a). Samples were taken at about 10-day intervals from June to September in 2009 and 2010. In 2010, three soil cores $(3 \mathrm{~cm}$ in diameter and $10 \mathrm{~cm}$ in depth) were taken adjacent to each PVC core; the samples were thoroughly mixed and sieved through a 2-mm mesh to obtain one composite sample for laboratory analysis of soil moisture content and $\mathrm{NH}_{4}{ }^{+}-\mathrm{N}$.

The absorbed $\mathrm{NH}_{3}$ was extracted from the sponges with $300-\mathrm{ml} \mathrm{KCl}$ solution $(1.0 \mathrm{M})$ and the extracts were measured using a flow injection auto analyzer (FIAstar 5000 Analyzer, Foss Tecator, Hillerød, Denmark). For soil $\mathrm{NH}_{4}{ }^{+}-\mathrm{N}$ measurements (details were 
described in Wang et al., 2006), 10-g fresh soil samples were extracted with $50-\mathrm{ml} \mathrm{KCl}$ solution $(2.0 \mathrm{M})$ and then analyzed using the flow injection auto analyzer. The soil $\mathrm{NH}_{4}{ }^{+}-\mathrm{N}$ concentration was expressed on the basis of dry soil. The soil water content (SWC) was determined using subsamples dried at $105^{\circ} \mathrm{C}$ for $48 \mathrm{~h}$ to constant weight.

\subsection{Statistical analysis}

Soil $\mathrm{NH}_{3}$ volatilization rates were calculated as daily volatilization, and monthly soil $\mathrm{NH}_{3}$ emissions were calculated on the basis of daily volatilization emission values. One-way ANOVA was used to analyze variation $(\alpha=0.05)$ in soil $\mathrm{NH}_{3}$ volatilization rates, soil monthly $\mathrm{NH}_{3}$ emissions, and soil $\mathrm{NH}_{3}$ emissions for grazing intensity during the 2009 and 2010 sampling periods. Repeated ANOVA was used to detect variation $(\alpha=0.05)$ in soil $\mathrm{NH}_{3}$ volatilization rates, soil $\mathrm{NH}_{3}$ emissions, soil $\mathrm{NH}_{4}{ }^{+}-\mathrm{N}, \mathrm{SWC}$ for sampling date, and interannual variations. Multiple linear regression was used to determine the relationships between monthly soil $\mathrm{NH}_{3}$ emissions, air temperature, and precipitation. The data were represented as mean $\pm \mathrm{SE}$ (standard error, $n=6$ ). All analyses were conducted using SPSS statistical software (version 10.0, SPSS Inc., Chicago, IL, USA). All graphs were obtained using SigmaPlot software (version 10.0, Systat Software, Inc., Chicago, IL, USA).

\section{Results}

\section{$2.1 \quad \mathrm{NH}_{3}$ volatilization rates from soil}

Soil $\mathrm{NH}_{3}$ volatilization rates ranged from 0.04 to $0.11 \mathrm{~kg}$ $\mathrm{N} /\left(\mathrm{hm}^{2} \cdot \mathrm{d}\right)$ in 2009 , and from 0.07 to $0.29 \mathrm{~kg} \mathrm{~N} /\left(\mathrm{hm}^{2} \cdot \mathrm{d}\right)$ in 2010 (Table 1, Fig. 2). For all treatments, soil $\mathrm{NH}_{3}$ volatilization rates increased from June to August, and then decreased in September. In 2009, soil $\mathrm{NH}_{3}$ volatilization rates in June, August, and September were

Table 1 Changes in soil $\mathrm{NH}_{3}$ volatilization rates $\left(\mathrm{kg} \mathrm{N} /\left(\mathrm{hm}^{2} \cdot \mathrm{d}\right)\right.$; mean $\left.(\mathrm{SE}), n=6\right)$ with increasing grazing intensities

\begin{tabular}{|c|c|c|c|c|c|c|}
\hline \multirow{2}{*}{ Year } & \multirow{2}{*}{ Month } & \multirow{2}{*}{ Day } & \multicolumn{4}{|c|}{ Grazing intensity (sheep $/ \mathrm{hm}^{2}$ ) } \\
\hline & & & 0.0 & 3.0 & 6.0 & 9.0 \\
\hline \multirow{11}{*}{2009} & \multirow{3}{*}{ Jun } & 5 & $0.057^{\mathrm{ab}}(0.003)$ & $0.071^{\mathrm{a}}(0.010)$ & $0.050^{\mathrm{b}}(0.004)$ & $0.058^{\mathrm{ab}}(0.005)$ \\
\hline & & 14 & $0.048^{\mathrm{ab}}(0.002)$ & $0.052^{\mathrm{a}}(0.005)$ & $0.041^{\mathrm{b}}(0.002)$ & $0.050^{\mathrm{ab}}(0.003)$ \\
\hline & & 24 & $0.076^{\mathrm{ns}}(0.006)$ & $0.069(0.008)$ & $0.069(0.005)$ & $0.081(0.013)$ \\
\hline & \multirow{3}{*}{ Jul } & 2 & $0.099^{\mathrm{a}}(0.009)$ & $0.062^{\mathrm{b}}(0.004)$ & $0.076^{\mathrm{b}}(0.006)$ & $0.077^{\mathrm{b}}(0.010)$ \\
\hline & & 14 & $0.071^{\text {ns }}(0.009)$ & $0.075(0.009)$ & $0.071(0.008)$ & $0.068(0.005)$ \\
\hline & & 24 & $0.085^{\mathrm{a}}(0.004)$ & $0.087^{\mathrm{a}}(0.005)$ & $0.070^{\mathrm{b}}(0.004)$ & $0.093^{\mathrm{a}}(0.007)$ \\
\hline & \multirow{3}{*}{ Aug } & 2 & $0.072^{\mathrm{ab}}(0.004)$ & $0.074^{\mathrm{ab}}(0.007)$ & $0.070^{\mathrm{b}}(0.004)$ & $0.086^{\mathrm{a}}(0.007)$ \\
\hline & & 14 & $0.084^{\mathrm{b}}(0.004)$ & $0.090^{\mathrm{ab}}(0.006)$ & $0.093^{\mathrm{ab}}(0.008)$ & $0.106^{\mathrm{a}}(0.012)$ \\
\hline & & 24 & $0.116^{\mathrm{b}}(0.006)$ & $0.149^{\mathrm{a}}(0.018)$ & $0.117^{\mathrm{b}}(0.007)$ & $0.117^{\mathrm{b}}(0.008)$ \\
\hline & \multirow{2}{*}{ Sep } & 2 & $0.102^{\text {ns }}(0.006)$ & $0.095(0.005)$ & $0.113(0.007)$ & $0.109(0.009)$ \\
\hline & & 14 & $0.079^{\text {ns }}(0.004)$ & $0.077(0.003)$ & $0.076(0.003)$ & $0.074(0.003)$ \\
\hline \multirow{10}{*}{2010} & \multirow[t]{2}{*}{ Jun } & 17 & $0.100^{c}(0.003)$ & $0.137^{\mathrm{b}}(0.012)$ & $0.171^{\mathrm{a}}(0.004)$ & $0.164^{\mathrm{a}}(0.012)$ \\
\hline & & 2 & $0.293^{\mathrm{a}}(0.020)$ & $0.180^{\mathrm{b}}(0.016)$ & $0.149^{\mathrm{b}}(0.003)$ & $0.270^{\mathrm{a}}(0.014)$ \\
\hline & \multirow[t]{2}{*}{ Jul } & 14 & $0.089^{\mathrm{b}}(0.002)$ & $0.117^{\mathrm{a}}(0.009)$ & $0.104^{\mathrm{ab}}(0.006)$ & $0.103^{\mathrm{ab}}(0.005)$ \\
\hline & & 24 & $0.220^{\mathrm{a}}(0.019)$ & $0.173^{\mathrm{b}}(0.009)$ & $0.145^{\mathrm{b}}(0.005)$ & $0.164^{\mathrm{b}}(0.004)$ \\
\hline & \multirow{3}{*}{ Aug } & 3 & $0.263^{\text {ns }}(0.027)$ & $0.222(0.016)$ & $0.262(0.028)$ & $0.197(0.026)$ \\
\hline & & 14 & $0.247^{\mathrm{ns}}(0.002)$ & $0.268(0.019)$ & $0.245(0.007)$ & $0.288(0.028)$ \\
\hline & & 24 & $0.156^{\mathrm{a}}(0.035)$ & $0.093^{\mathrm{b}}(0.001)$ & $0.114^{\mathrm{ab}}(0.007)$ & $0.121^{\mathrm{ab}}(0.003)$ \\
\hline & \multirow{3}{*}{ Sep } & 2 & $0.074^{\mathfrak{c}}(0.005)$ & $0.086^{\mathrm{bc}}(0.005)$ & $0.130^{\mathrm{a}}(0.017)$ & $0.104^{\mathrm{b}}(0.004)$ \\
\hline & & 14 & $0.101^{\mathrm{b}}(0.012)$ & $0.172^{\mathrm{a}}(0.009)$ & $0.164^{\mathrm{a}}(0.024)$ & $0.110^{\mathrm{b}}(0.003)$ \\
\hline & & 23 & $0.076^{\mathrm{ns}}(0.008)$ & $0.076(0.009)$ & $0.083(0.005)$ & $0.087(0.002)$ \\
\hline
\end{tabular}

Note: The superscripts indicate significant differences between different treatments in a row (LSD, $P \leq 0.05) .{ }^{\mathrm{ns}}$ indicates no significant difference within the row. 

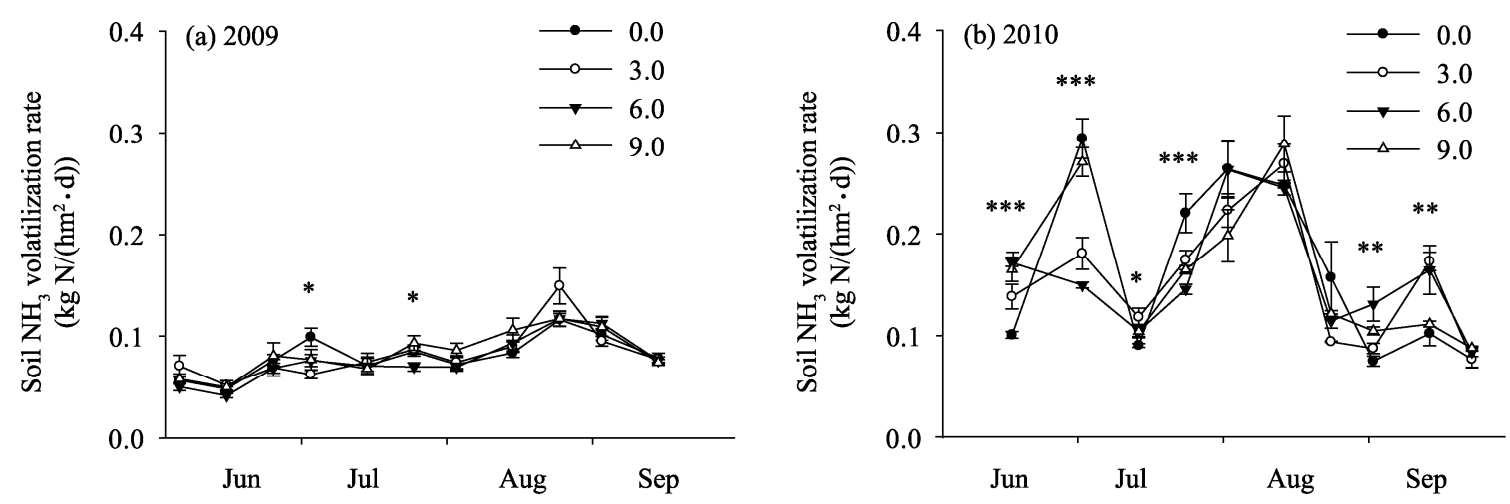

Fig. 2 Changes in soil $\mathrm{NH}_{3}$ volatilization rates for different grazing intensities. Grazing intensities are designated as 0.0 (no grazing), 3.0 sheep $/ \mathrm{hm}^{2}, 6.0$ sheep $/ \mathrm{hm}^{2}$, and 9.0 sheep $/ \mathrm{hm}^{2}$ in both 2009 (a) and 2010 (b). Asterisks denote significant differences between the different treatments in the given periods $\left({ }^{*}, P \leq 0.05 ;{ }^{* *}, P \leq 0.01\right.$; and $\left.{ }^{* * *}, P \leq 0.001\right)$.

not significantly different for the different grazing intensities (Fig. 2a). The results of repeated ANOVA showed that grazing intensity (GI) had no significant influence on soil $\mathrm{NH}_{3}$ volatilization rates $(P=0.194)$. However, sampling date, interannual variations, and their interactions all significantly impacted soil $\mathrm{NH}_{3}$ volatilization rates (Table 2, $P<0.001$ ). Combined with the two-year data, GI had no influence on soil $\mathrm{NH}_{3}$ volatilization rates $(P=0.088$, Table 3$)$. Otherwise, there were no interaction effects between GI and date under omitted interannual variations $(P=0.085$, Table 3$)$. Overall, soil $\mathrm{NH}_{3}$ volatilization rates were higher in 2010 than in 2009 (Table 2, Fig. 2).

The results show that soil $\mathrm{NH}_{4}{ }^{+}-\mathrm{N}$ concentration $(\mathrm{mg} \mathrm{N} / \mathrm{kg})(P=0.589)$ and SWC $(P=0.728)$ did not vary significantly with increasing grazing intensities. Soil $\mathrm{NH}_{3}$ volatilization rates were not related to soil $\mathrm{NH}_{4}{ }^{+}-\mathrm{N}$ (Fig. 3a), but were significantly related to SWC (Fig. 3b, $P<0.001$ ) and air temperature (Fig. 3c, $P<0.001)$.

Table 2 Results of repeated ANOVA of sampling date (D), year $(\mathrm{Y})$, grazing intensity $(\mathrm{GI})$, and their interactions with soil $\mathrm{NH}_{3}$ volatilization rates

\begin{tabular}{lccrr}
\hline & $d f$ & Mean square & \multicolumn{1}{c}{$F$} & \multicolumn{1}{c}{$P$} \\
\hline $\mathrm{D}$ & 9 & 0.05 & 60.18 & $<0.001$ \\
$\mathrm{Y}$ & 1 & 0.66 & 629.25 & $<0.001$ \\
$\mathrm{GI}$ & 3 & 0.00 & 1.63 & 0.194 \\
$\mathrm{D} \times \mathrm{Y}$ & 9 & 0.07 & 88.82 & $<0.001$ \\
$\mathrm{D} \times \mathrm{GI}$ & 27 & 0.01 & 5.88 & $<0.001$ \\
$\mathrm{Y} \times \mathrm{GI}$ & 3 & 0.00 & 0.58 & 0.629 \\
$\mathrm{D} \times \mathrm{Y} \times \mathrm{GI}$ & 27 & 0.01 & 5.88 & $<0.001$ \\
\hline
\end{tabular}

\section{2 $\mathrm{NH}_{3}$ emissions from soil}

Soil $\mathrm{NH}_{3}$ emissions increased from June to August, and then decreased in September, for all grazing intensities (Fig. 4). The monthly soil $\mathrm{NH}_{3}$ emissions did not differ significantly for different grazing intensities in 2009 (Fig. 4a). In 2010, there was no clear trend in the monthly soil $\mathrm{NH}_{3}$ emissions (Fig. 4b). During the grazing period, the cumulative soil $\mathrm{NH}_{3}$ emissions were $9.6 \pm 0.2 \mathrm{~kg} \mathrm{~N} / \mathrm{hm}^{2}$ from June to September in 2009, and 19.0 $\pm 0.2 \mathrm{~kg} \mathrm{~N} / \mathrm{hm}^{2}$ in 2010 (Fig. 4). Repeated ANOVA showed no significant differences between GI and cumulative soil $\mathrm{NH}_{3}$ emissions when the two seasons were combined $(P=0.689)$. Moreover, cumulative soil $\mathrm{NH}_{3}$ emissions were not significantly different between different grazing intensities during the 2009 grazing period. The emissions showed an increasing trend at all grazing pressures in 2010 (Fig. 4). There was a significant interannual variation in cumulative soil $\mathrm{NH}_{3}$ emissions (Table $3, P<0.001$ ). Overall, increasing grazing intensities did not influence cumulative soil $\mathrm{NH}_{3}$ emissions from grassland in comparison with no-grazing (control) plots (Fig. 4, Table 3).

Moreover, monthly soil $\mathrm{NH}_{3}$ emissions increased with increasing monthly soil $\mathrm{NH}_{4}{ }^{+}-\mathrm{N}(P=0.068$, Fig. 5a) and monthly air temperature $(P=0.010$, Fig. 6a). Conversely, monthly soil $\mathrm{NH}_{3}$ emissions decreased to some extent with increasing monthly SWC $(P=0.062$, Fig. $5 b)$ and monthly precipitation $(P=0.140$, Fig. $6 b)$. The linear regression model (Eq. 1) comprising monthly air temperature and precipitation well described 

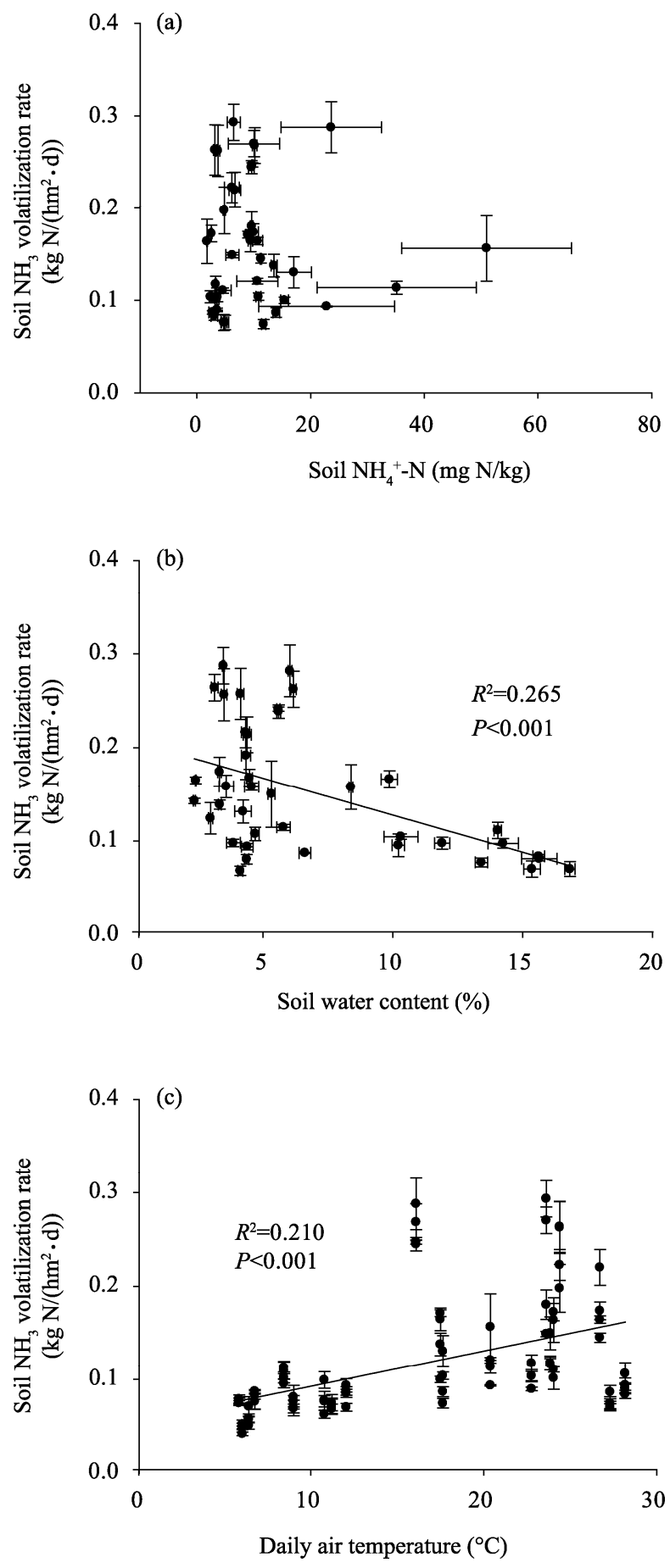

Fig. 3 Relationship between soil $\mathrm{NH}_{3}$ volatilization rates (kg $\left.\mathrm{N} /\left(\mathrm{hm}^{2} \cdot \mathrm{d}\right)\right)$ and soil $\mathrm{NH}_{4}{ }^{+}-\mathrm{N}(\mathrm{a})$, soil water content (b) in 2010 and daily air temperature (c) during 2009-2010

the changes in soil $\mathrm{NH}_{3}$ emissions $(r=0.506, P=0.014)$.

$$
z=1.085+0.188 x-0.022 y \text {. }
$$

Where $z, x$, and $y$ are monthly soil $\mathrm{NH}_{3}$ emission $(\mathrm{kg}$ $\mathrm{N} / \mathrm{hm}^{2}$ ), monthly air temperature $\left({ }^{\circ} \mathrm{C}\right)$, and monthly precipitation (mm), respectively.

\section{Discussion}

\subsection{Effects of grazing on soil $\mathrm{NH}_{3}$ emissions}

Our findings from a 5-year experiment involving sheep grazing intensities in Inner Mongolian grasslands showed that grazing intensity has no apparent impact on soil $\mathrm{NH}_{3}$ emissions. We found that soil $\mathrm{NH}_{3}$ volatilization rates were $0.07-0.29 \mathrm{~kg} \mathrm{~N} /\left(\mathrm{hm}^{2} \cdot \mathrm{d}\right)$ in the summer period (averaged as $0.22 \mathrm{~kg} \mathrm{~N} /\left(\mathrm{hm}^{2} \cdot \mathrm{d}\right)$ ) in Inner Mongolian grasslands, which is similar to that reported in Canberra, Australia (Denmead et al., 1974). The soil $\mathrm{NH}_{3}$ emissions in the grazing season ranged from 9.6 to $19.0 \mathrm{~kg} \mathrm{~N} / \mathrm{hm}^{2}$ (averaged as $14.3 \mathrm{~kg}$ $\mathrm{N} / \mathrm{hm}^{2}$ ), which was consistent with the results from Australian grazed pastures (Eckard et al., 2003), but higher than the results from the grazing grasslands in Yellowstone National Park (Frank and Zhang, 1997) and in Californian native grassland soil (Potter et al., 2003). The lower air temperature and higher precipitation in 2009 may partly explain the lower soil $\mathrm{NH}_{3}$ emissions in 2009 than in 2010. Lower air temperature and higher precipitation could inhibit $\mathrm{NH}_{3}$ emissions owing to lowered urease activity and $\mathrm{NH}_{3}$ diffusion (Harper et al., 1983). In some previous studies, plant-soil interface $\mathrm{NH}_{3}$ emissions were very low in undisturbed ecosystems, and increased with grazing-animal density (Bowden, 1986). Many studies indicated that animal grazing in grassland ecosystems could stimulate $\mathrm{NH}_{3}$ emissions, primarily because of the increasing amounts of animal urine and feces (Bowden, 1986; Bussink and Oenema, 1998). In this study, the direct effects of livestock feces on $\mathrm{NH}_{3}$ emissions were not measured, but the potential effect of inorganic $\mathrm{N}$ decomposed and leached from feces into soil was considered. Soil $\mathrm{NH}_{4}{ }^{+}-\mathrm{N}$ concentration was not significantly different for different grazing intensities in our study, or in the findings reported by Shan et al. (2011). Previous studies demonstrated that net ammonification and gross $\mathrm{N}$ mineralization were not affected by grazing intensities during grazing seasons in central Argentina (Andrioli et al., 2010) and Inner Mongolia (Wu et al., 2011). It was reported that soil $\mathrm{NO}_{3}{ }^{-} \mathrm{N}$ concentration increased with increasing grazing intensity and that at the highest grazing 
Table 3 Results of repeated ANOVA for sampling date (D), grazing intensity (GI), and their interactions with soil $\mathrm{NH}_{3}$ volatilization rates; and results of repeated ANOVA of year $(\mathrm{Y}), \mathrm{Gl}$, and their interactions with soil $\mathrm{NH}_{3}$ cumulative emissions, when considering the continued impacts of grazing on soil $\mathrm{NH}_{3}$ emissions

\begin{tabular}{|c|c|c|c|c|c|c|c|c|c|}
\hline & \multicolumn{4}{|c|}{ Soil $\mathrm{NH}_{3}$ volatilization rate } & & \multicolumn{3}{|c|}{ Cumulative soil $\mathrm{NH}_{3}$ emission } & \multirow[b]{2}{*}{$P$} \\
\hline & $d f$ & Mean square & $F$ & $P$ & & $d f$ & Mean square & $F$ & \\
\hline $\mathrm{D}$ & 20 & 18.68 & $1,618.00$ & $<0.001$ & $\mathrm{Y}$ & 1 & 974.73 & 826.77 & $<0.001$ \\
\hline GI & 3 & 0.03 & 2.60 & 0.088 & GI & 3 & 0.41 & 0.50 & 0.689 \\
\hline $\mathrm{D} \times \mathrm{GI}$ & 60 & 0.03 & 2.51 & 0.085 & $\mathrm{Y} \times \mathrm{GI}$ & 3 & 3.07 & 2.60 & 0.080 \\
\hline
\end{tabular}
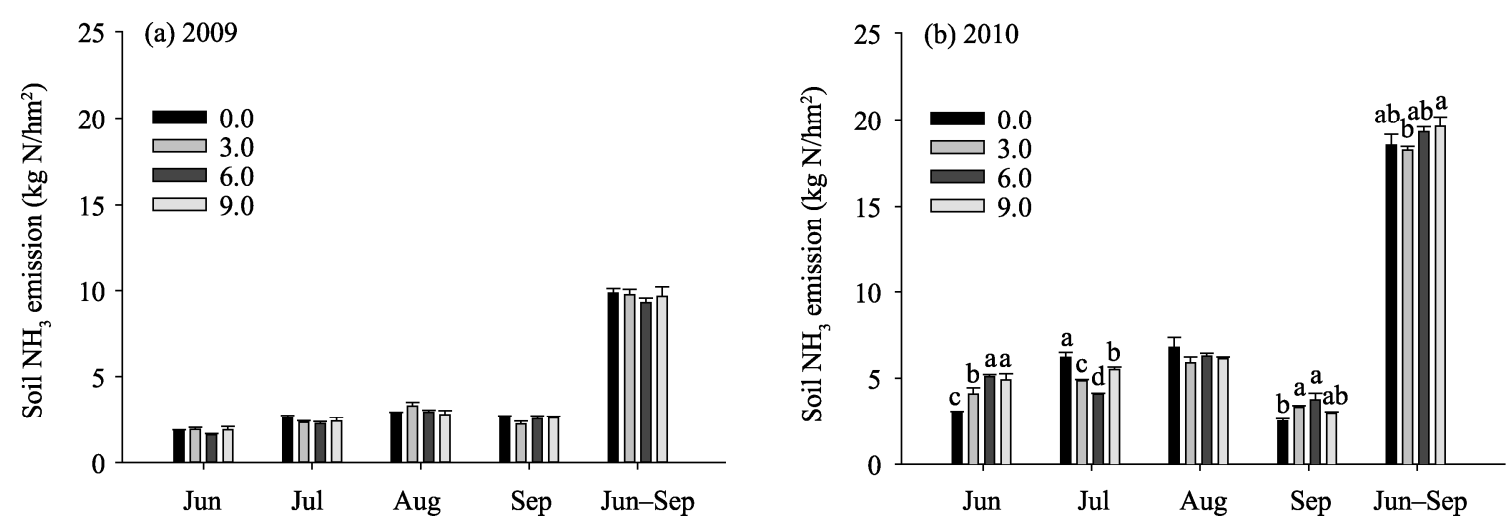

Fig. 4 Changes in monthly soil $\mathrm{NH}_{3}$ emissions with increasing grazing intensities. Grazing intensities are designated as 0.0 (no grazing), 3.0 sheep/hm $\mathrm{hm}^{2}, 6.0$ sheep/ $/ \mathrm{hm}^{2}$, and 9.0 sheep/ $/ \mathrm{hm}^{2}$ in both 2009 (a) and 2010 (b). Jun-Sep indicates the cumulative $\mathrm{NH}_{3}$ emissions from June to September. The letters above the columns indicate significant differences between different grazing intensities; $P \leq 0.05$.
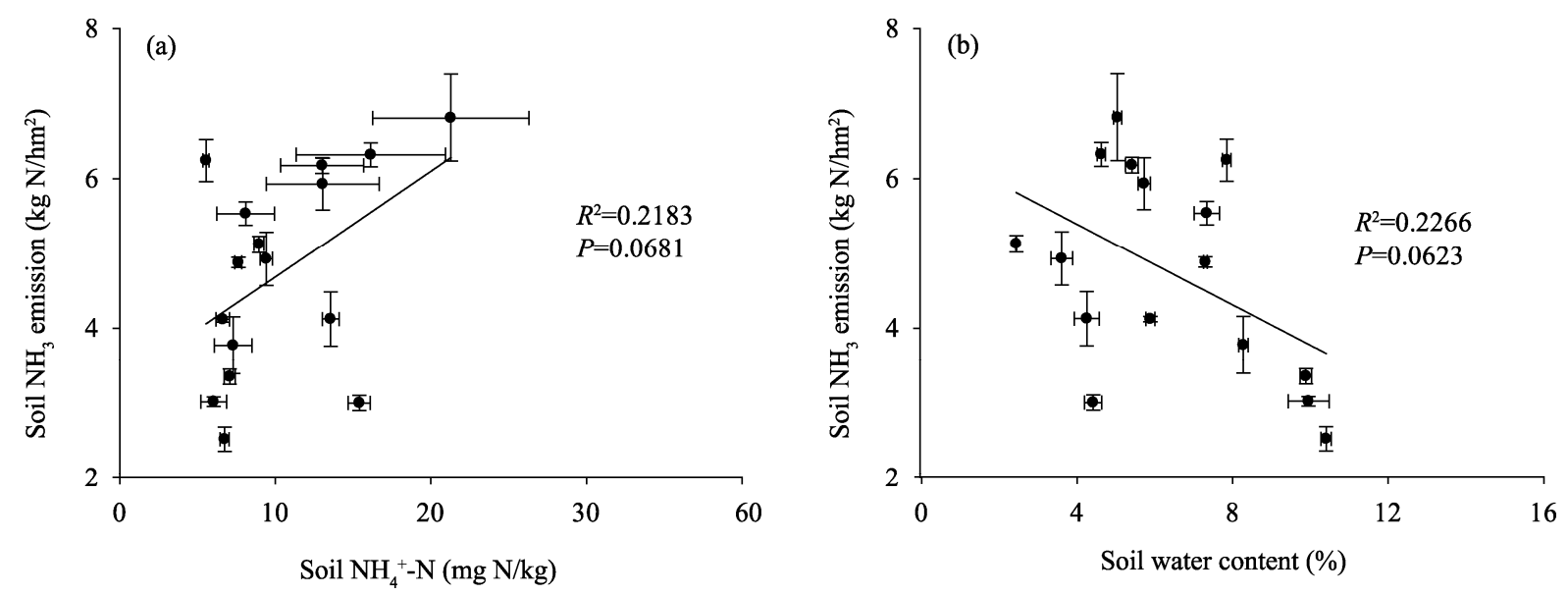

Fig. 5 Relationship of monthly soil $\mathrm{NH}_{3}$ emissions with soil $\mathrm{NH}_{4}{ }^{+} \mathrm{N}(\mathrm{a})$ and soil water content (b) in 2010

intensity, soil $\mathrm{NO}_{3}{ }^{-} \mathrm{N}$ concentration was 10 times that of soil $\mathrm{NH}_{4}{ }^{+}-\mathrm{N}(\mathrm{Wu}, 2011)$. Wu (2011) found that the average ${ }^{15} \mathrm{NH}_{4}{ }^{+}-\mathrm{N}$ residence time in soil was approximately $2.8,6.3,2.3$, and 1.5 days, respectively, at the grazing intensities of $0.0,1.5,4.5$, and 7.5 sheep $/ \mathrm{hm}^{2}$. We infer from their finding that the shortened residence time of $\mathrm{NH}_{4}{ }^{+}-\mathrm{N}$ and accumulation of $\mathrm{NO}_{3}{ }^{-} \mathrm{N}$ in the soil, triggered by high grazing intensity, may explain why soil $\mathrm{NH}_{3}$ emissions in Inner Mongo- lian grasslands did not increase at higher grazing intensities. Moreover, we may also infer that the increased $\mathrm{NH}_{3}$ emissions from grazing grassland were mainly the result of increased sheep excretion of feces and urine (Laubach et al., 2012).

\subsection{Controlling factors of $\mathrm{NH}_{3}$ emissions from soil by grazing in grasslands}

Soil $\mathrm{NH}_{3}$ volatilization is a physical-chemical reaction 

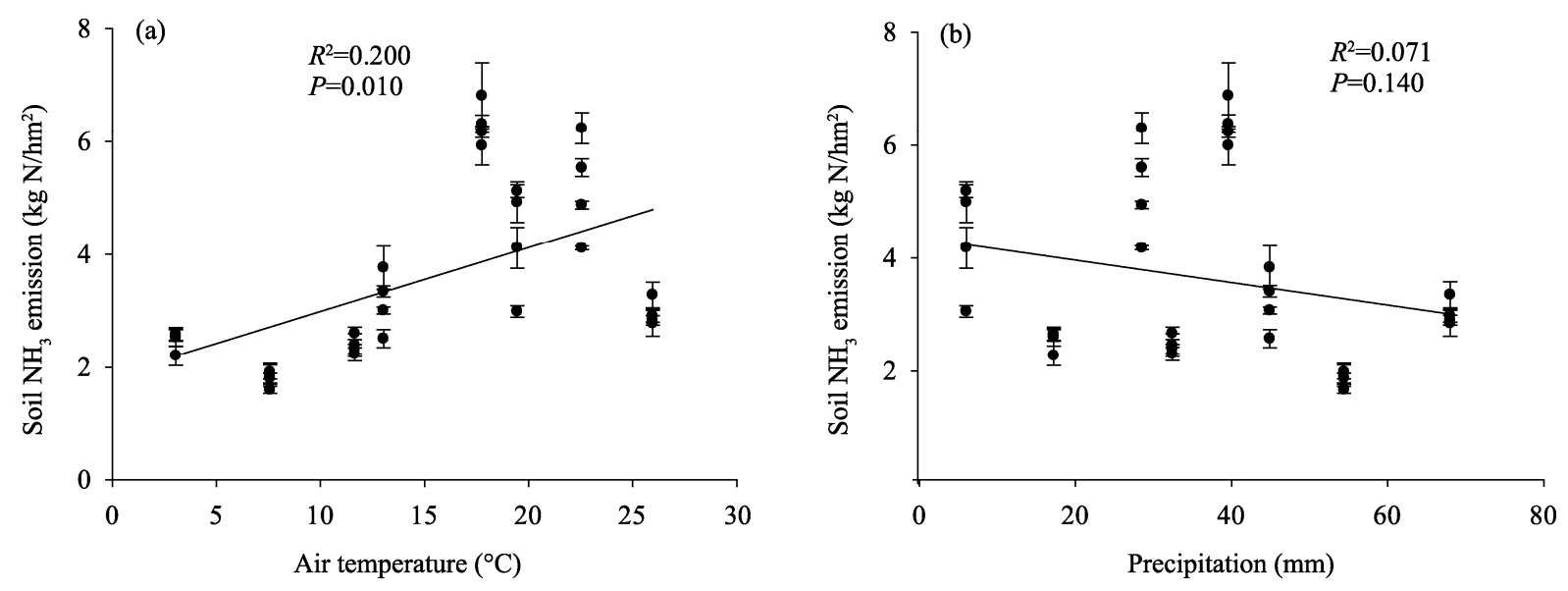

Fig. 6 Relationship of monthly soil $\mathrm{NH}_{3}$ emissions with air temperature (a) and monthly precipitation (b) during 2009-2010

that is influenced by soil $\mathrm{NH}_{4}{ }^{+}-\mathrm{N}$ concentration, temperature, soil moisture, soil $\mathrm{pH}$, and other environmental factors (Mills et al., 1974; McCalley and Sparks, 2008; Zaman et al., 2009). Soil temperature influences $\mathrm{NH}_{4}{ }^{+}$absorption, conversion of $\mathrm{NH}_{4}{ }^{+}$into $\mathrm{NH}_{3}$, and $\mathrm{NH}_{3}$ emissions (Fenn and Kissel, 1974), and temperature-induced effects on soil $\mathrm{NH}_{3}$ volatilization are significant only within a narrow range of temperatures (Liu et al., 2007a). A previous study in the Inner Mongolia region reported that intense grazing had no influence on soil temperature during the grazing period (Zhao et al., 2011). Furthermore, SWC greatly retarded $\mathrm{NH}_{3}$ diffusion from soil because $\mathrm{NH}_{3}$ is highly soluble in water and its diffusion coefficient is far lower in wet soil than in air (Fenn and Escarzaga, 1976; Liu et al., 2007b). At the same study site, SWC was not decreased when grazing pressure increased (Shan et al., 2011). Moreover, soil pH values greatly influence the $\mathrm{NH}_{4}^{+} / \mathrm{NH}_{3}$ ratio, and to some extent control $\mathrm{NH}_{3}$ volatilization potential (Rao and Batra, 1983; Fleisher et al., 1987). Smith et al. (2009) demonstrated that lower $\mathrm{pH}$ soils have a lower potential of $\mathrm{NH}_{3}$ emissions than soils with higher $\mathrm{pH}$ values. The $\mathrm{pH}$ of the topsoil did not decrease with increasing grazing intensities in our study or in that of Shan et al. (2011). Other basic factors affected by grazing during the sampling period do not differ significantly at different grazing intensities in our experimental grassland ecosystem. These include soil $\mathrm{NH}_{4}{ }^{+}-\mathrm{N}$ concentration (Shan et al., 2011) and net $\mathrm{N}$ mineralization rates at the present study area and an adjacent grazed grassland (Xu et al., 2007). Further, since our study area had a high density of free animal grazing (sheep and cows) prior to 2005, the effects of the treatments on soil texture may not become apparent (Wittmer et al., 2011). Overall, in our experiments, the factors mentioned above showed no apparent change with increasing grazing intensities compared to the control treatment, which indicated that $\mathrm{NH}_{3}$ volatilization from soil was not affected by increasing grazing pressure.

\subsection{Implications for the estimation of soil $\mathrm{NH}_{3}$ emissions}

Our findings showed that monthly soil $\mathrm{NH}_{3}$ emissions were significantly related to monthly air temperatures and precipitation, which was well simulated by the linear regression model (Eq. 1). The model could be used to estimate soil $\mathrm{NH}_{3}$ emissions from grasslands on a regional scale, given the conclusion that grazing pressure has no effect on soil $\mathrm{NH}_{3}$ emissions compared to the ungrazed control treatment. In other words, grazing intensities had less effect than climatic factors on $\mathrm{NH}_{3}$ emissions from soil (Hatch et al., 1990). As the Chinese government has implemented a "Grain for Green" program, natural grasslands are now being managed under lower or appropriate grazing intensities (Cao et al., 2011). In view of the improved understanding of soil carbon and nitrogen storage, a stocking density of approximately 4.5 sheep $/ \mathrm{hm}^{2}$ (grazing period from June to September) should be specified as the sustainable grazing intensity for Inner Mongolian grasslands (He et al., 2011). Our results also showed that the ungrazed plot had similar 
soil $\mathrm{NH}_{3}$ emissions to a moderate grazing treatment (6.0 sheep $/ \mathrm{hm}^{2}$ ). Under this grazing pressure, and with regard to spatial variability, we estimated that soil $\mathrm{NH}_{3}$ emissions during the June-September grazing period from the Xilinguole League of Inner Mongolia, which includes $9.0 \times 10^{6} \mathrm{hm}^{2}$ of typical natural pasture, was about $0.9 \times 10^{8} \mathrm{~kg} \mathrm{~N}$ in 2009 and $1.7 \times 10^{8} \mathrm{~kg} \mathrm{~N}$ in 2010. These results differ from those of Bowden (1986), who estimated that the annual soil $\mathrm{NH}_{3}$ emissions from ungrazed or lightly grazed grasslands ranged from 0 to $10 \mathrm{~kg} \mathrm{~N} / \mathrm{hm}^{2}$. Our findings showed that ungrazed grasslands have a high potential of emitting $\mathrm{NH}_{3}$ from soils; this raises the possibility that $\mathrm{NH}_{3}$ emissions from these undisturbed grassland soils were not similar in previous studies (Bowden, 1986; Schlesinger and Hartley, 1992), with disparities resulting from different analytical and field techniques.

\section{Conclusions}

Grazing intensities had no apparent effect on soil $\mathrm{NH}_{3}$ emissions in Inner Mongolian grasslands compared to an ungrazed treatment (control). Soil $\mathrm{NH}_{3}$ emissions in the grazing period ranged from 9.6 to $19.0 \mathrm{~kg}$ $\mathrm{N} / \mathrm{hm}^{2}$ (averaged as $14.3 \mathrm{~kg} \mathrm{~N} / \mathrm{hm}^{2}$ ) in 2009 and 2010. Our findings showed that the monthly soil $\mathrm{NH}_{3}$ emissions were significantly related to monthly air temperature and precipitation, and that linear regression well depicted the changes in soil $\mathrm{NH}_{3}$ emissions. Moreover, ungrazed grasslands have a high capacity for emitting soil $\mathrm{NH}_{3}$, which is greater than that of soil $\mathrm{NH}_{3}$ emissions reported previously in other undisturbed grasslands. Our results may be influenced by the heavy grazing of the area prior to our experiment; therefore, longer-term studies may be required to determine the ongoing effects of previous management regimes in this area. More studies of $\mathrm{NH}_{3}$ from ungulate feces and urine are needed in Inner Mongolian grasslands. Our research provides a new insight into soil $\mathrm{NH}_{3}$ volatilization from Eurasian steppe under different stocking densities, which is important for the understanding $\mathrm{N}$ cycles in grassland ecosystems and for predicting regional $\mathrm{NH}_{3}$ emissions from soil.

\section{Acknowledgements}

Funding for this work came from the National Natural Science
Foundation of China (30830026), the National Basic Research Program of China (2009CB825103), and the Innovative Research Group Project of the National Natural Science Foundation of China (30821062). We thank YuMei SHAN, JianJun CHEN, YingJie DONG, LiXin XU, QingFang ZHENG, GuoHua LI, and YinHua HAN for their assistance with field samplings, and the Inner Mongolia Grassland Ecosystem Research Station for help with laboratory analysis. The authors thank four anonymous reviewers for their helpful comments on the manuscript.

\section{References}

Andrioli R J, Distel R A, Didoné N G. 2010. Influence of cattle grazing on nitrogen cycling in soils beneath Stipa tenuis, native to central Argentina. Journal of Arid Environments, 74(3): 419-422.

Asman W A H, Sutton M A, Schjorring J K. 1998. Ammonia: emission, atmospheric transport and deposition. New Phytologist, 139(1): $27-48$.

Battye W, Aneja V P, Roelle P A. 2003. Evaluation and improvement of ammonia emissions inventories. Atmospheric Environment, 37(27): 3873-3883.

Bolan N S, Saggar S, Luo J F, et al. 2004. Gaseous emissions of nitrogen from grazed pastures: processes, measurements and modelling, environmental implications, and mitigation. Advances in Agronomy, 84: $37-120$.

Bowden W B. 1986. Gaseous nitrogen emmissions from undisturbed terrestrial ecosystems: an assessment of their impacts on local and global nitrogen budgets. Biogeochemistry, 2(3): 249-279.

Bussink D W, Oenema O. 1998. Ammonia volatilization from dairy farming systems in temperate areas: a review. Nutrient Cycling in Agroecosystems, 51(1): 19-33.

Cao S X, Sun G, Zhang Z Q, et al. 2011. Greening China naturally. AMBIO, 40(7): 828-831.

Chen Z Z. 1988. Topography and climate of Xilin River Basin. In: Inner Mongolia Grassland Ecosystem Research Station. Research on Grassland Ecosystem. Beijing: Science Press, 13-22.

Clarisse L, Clerbaux C, Dentener F, et al. 2009. Global ammonia distribution derived from infrared satellite observations. Nature Geoscience, 2(7): 479-483.

Denmead O T, Simpson J R, Freney J R. 1974. Ammonia flux into the atmosphere from a grazed pasture. Science, 185(4151): 609-610.

Eckard R J, Chen D, White R E, et al. 2003. Gaseous nitrogen loss from temperate perennial grass and clover dairy pastures in south-eastern Australia. Crop and Pasture Science, 54(6): 561-570.

Feng X M, Zhao Y S. 2011. Grazing intensity monitoring in Northern China steppe: integrating CENTURY model and MODIS data. Ecological Indicators, 11(1): 175-182.

Fenn L B, Kissel D E. 1974. Ammonia volatilization from surface applications of ammonium-compounds on calcareous soils: II. ef- 
fects of temperature and rate of ammonium nitrogen application. Soil Science Society of America Journal, 38(4): 606-610.

Fenn L B, Escarzaga R. 1976. Ammonia volatilization from surface applications of ammonium-compounds on calcareous soils: V. soil-water content and method of nitrogen application. Soil Science Society of America Journal, 40(4): 537-541.

Fleisher Z, Kenig A, Ravina I, et al. 1987. Model of ammonia volatilization from calcareous soils. Plant and Soil, 103(2): 205-212.

Frank D A, Zhang Y M. 1997. Ammonia volatilization from a seasonally and spatially variable grazed grassland: Yellowstone National Park. Biogeochemistry, 36(2): 189-203.

Frank D A, Evans R D, Tracy B F. 2004. The role of ammonia volatilization in controlling the natural ${ }^{15} \mathrm{~N}$ abundance of a grazed grassland. Biogeochemistry, 68(2): 169-178.

Harper L A, Catchpoole V R, Davis R, et al. 1983. Ammonia volatilization: soil, plant, and microclimate effects on diurnal and seasonal fluctuations. Agronomy Journal, 75(2): 212-218.

Hatch D J, Jarvis S C, Dollard G J. 1990. Measurements of ammonia emission from grazed grassland. Environmental Pollution, 65(4): 333-346.

He N P, Zhang Y H, Yu Q, et al. 2011. Grazing intensity impacts soil carbon and nitrogen storage of continental steppe. Ecosphere, 2(1): art8. doi: 10.1890/ES10-00017.1

He N P, Zhang Y H, Dai J Z, et al. 2012. Land-use impact on soil carbon and nitrogen sequestration in typical steppe ecosystems, Inner Mongolia. Journal of Geographical Sciences, 22(5): 859-873.

Hutchings N J, Sommer S G, Jarvis S C. 1996. A model of ammonia volatilization from a grazing livestock farm. Atmospheric Environment, 30(4): 589-599.

Jiang Y, Bi X L, Huang J H, et al. 2011. Patterns and drivers of vegetation degradation in Xilin River Basin, Inner Mongolia, China. Chinese Journal of Plant Ecology, 34(10): 1132-1141.

Laubach J, Taghizadeh-Toosi A, Sherlock R R, et al. 2012. Measuring and modelling ammonia emissions from a regular pattern of cattle urine patches. Agricultural and Forest Meteorology, 156: 1-17.

Liu G D, Li Y C, Alva A K. 2007a. Temperature quotients of ammonia emission of different nitrogen sources applied to four agricultural soils. Soil Science Society of America Journal, 71(5): 1482-1489.

Liu G D, Li Y C, Alva A K. 2007b. Moisture quotients for ammonia volatilization from four soils in potato production regions. Water, Air \& Soil Pollution, 183(1-4): 115-127.

McCalley C K, Sparks J P. 2008. Controls over nitric oxide and ammonia emissions from Mojave Desert soils. Oecologia, 156(4): $871-881$

Mills H A, Barker A V, Maynard D N. 1974. Ammonia volatilization from soils. Agronomy Journal, 66(3): 355-358.

Myles L T. 2009. Atmospheric science: underestimating ammonia. Nature Geoscience, 2(7): 461-462.

Potter C, Klooster S, Krauter C. 2003. Regional modeling of ammonia emissions from native soil sources in California. Earth Interactions, 7(11): 1-28.

Rao D L N, Batra L. 1983. Ammonia volatilization from applied nitrogen in alkali soils. Plant and Soil, 70(2): 219-228.

Renner E, Wolke R. 2010. Modelling the formation and atmospheric transport of secondary inorganic aerosols with special attention to regions with high ammonia emissions. Atmospheric Environment, 44(15): 1904-1912.

Ruess R W, McNaughton S J. 1988. Ammonia volatilization and the effects of large grazing mammals on nutrient loss from East African grasslands. Oecologia, 77(3): 382-386.

Schlesinger W H, Hartley A E. 1992. A global budget for atmospheric $\mathrm{NH}_{3}$. Biogeochemistry, 15(3): 191-211.

Schönbach P, Wan H, Schiborra A, et al. 2009. Short-term management and stocking rate effects of grazing sheep on herbage quality and productivity of Inner Mongolia steppe. Crop and Pasture Science, 60(10): 963-974.

Shan Y M, Chen D M, Guan X X, et al. 2011. Seasonally dependent impacts of grazing on soil nitrogen mineralization and linkages to ecosystem functioning in Inner Mongolia grassland. Soil Biology and Biochemistry, 43(9): 1943-1954.

Sheppard L J, Leith I D, Mizunuma T, et al. 2011. Dry deposition of ammonia gas drives species change faster than wet deposition of ammonium ions: Evidence from a long-term field manipulation. Global Change Biology, 17(12): 3589-3607.

Smart J C R, Hicks K, Morrissey T, et al. 2011. Applying the ecosystem service concept to air quality management in the UK: a case study for ammonia. Environmetrics, 22(5): 649-661.

Smith E, Gordon R, Bourque C, et al. 2009. Simulated management effects on ammonia emissions from field applied manure. Journal of Environmental Management, 90(8): 2531-2536.

Stevens C J, Tilman D. 2010. Point source ammonia emissions are having a detrimental impact on prairie vegetation. Water, Air, \& Soil Pollution, 211(1-4): 435-441.

Walker J T, Whitall D R, Robarge W, et al. 2004. Ambient ammonia and ammonium aerosol across a region of variable ammonia emission density. Atmospheric Environment, 38(9): 1235-1246.

Wang C H, Wan S Q, Xing X R, et al. 2006. Temperature and soil moisture interactively affected soil net $\mathrm{N}$ mineralization in temperate grassland in Northern China. Soil Biology and Biochemistry, 38(5): 1101-1110.

Wang J, Baoyin T G T. 2005. The study on characteristics of biomass composition of natural Leymus chinensis steppe on a deteriorated series in Neimongol. Acta Scientiarum Naturalium Universitatis Neimongol, 36(2): 155-160.

Wang J W, Cai Y C. 1988. Studies on genesis, types and characteristics of the soils of the Xilin River Basin. In: Inner Mongolia Grassland Ecosystem Research Station. Research on Grassland Ecosystem. Beijing: Science Press, 23-83. 
Wang Z H, Liu X J, Ju X T, et al. 2004. Ammonia volatilization loss from surface-broadcast urea: Comparison of vented- and closed-chamber methods and loss in winter wheat-summer maize rotation in North China Plain. Communications in Soil Science and Plant Analysis, 35(19-20): 2917-2939.

Webb J, Misselbrook T H. 2004. A mass-flow model of ammonia emissions from UK livestock production. Atmospheric Environment, 38(14): 2163-2176.

Wittmer M H O M, Auerswald K, Schönbach P, et al. $2011 .{ }^{15} \mathrm{~N}$ fractionation between vegetation, soil, faeces and wool is not influenced by stocking rate. Plant and Soil, 340(1-2): 25-33.

Wu H H. 2011. The effect of grazing on N turnover in the Inner Mongolia Steppe. PhD Dissertation. Beijing: Graduate University of Chinese Academy of Sciences, 28-56.

Wu H H, Dannenmann M, Fanselow N, et al. 2011. Feedback of grazing on gross rates of $\mathrm{N}$ mineralization and inorganic $\mathrm{N}$ partitioning in steppe soils of Inner Mongolia. Plant and Soil, 340(1-2): 127-139.
Xiao H W, Xiao H Y, Long A M, et al. 2012. Who controls the monthly variations of $\mathrm{NH}_{4}^{+}$nitrogen isotope composition in precipitation? Atmospheric Environment, 54: 201-206.

Xu Y Q, Li L H, Wang Q B, et al. 2007. The pattern between nitrogen mineralization and grazing intensities in an Inner Mongolian typical steppe. Plant and Soil, 300(1-2): 289-300.

$\mathrm{Xu} \mathrm{Y} \mathrm{Q,} \mathrm{He} \mathrm{J} \mathrm{C,} \mathrm{Li} \mathrm{L} \mathrm{H,} \mathrm{et} \mathrm{al.} \mathrm{2010.} \mathrm{Ammonia} \mathrm{volatilization} \mathrm{in} \mathrm{a}$ semi-arid rangeland in Inner Mongolia. Journal of Resources and Ecology, 1(1): 68-74.

Zaman M, Saggar S, Blennerhassett J D, et al. 2009. Effect of urease and nitrification inhibitors on $\mathrm{N}$ transformation, gaseous emissions of ammonia and nitrous oxide, pasture yield and $\mathrm{N}$ uptake in grazed pasture system. Soil Biology and Biochemistry, 41(6): 1270-1280.

Zhao Y, Peth S, Reszkowska A, et al. 2011. Response of soil moisture and temperature to grazing intensity in a Leymus chinensis steppe, Inner Mongolia. Plant and Soil, 340(1-2): 89-102. 